\title{
Overconfidence, Ownership Control and Financial Distress in Different Types of State-Owned Enterprises: Evidence from China
}

\author{
Abraham Simon Otim Emuron*, Tian Yixiang, Cephas Paa Kwasi Coffie and \\ Evans Opoku-Mensah \\ School of Management and Economics, University of Electronic Science and \\ Technology of China, Chengdu, China \& Center of West African Studies, University \\ of Electronic Science and Technology of China, Chengdu, China
}

\begin{abstract}
This study distinguished between the different forms of ownership in China's listed state-owned enterprises (SOEs) and then examined how managerial overconfidence within these forms of ownership control affects firms' likelihood of facing distress. Ownership control was categorized into distinct forms of ownership, namely, state asset management bureaus (SAMBs), state owned enterprises (SOEs) affiliated to the central government (SOECGs), and SOEs affiliated to the local government (SOELGs). Using a sample of China's listed SOEs from 2003 - 2018 this study empirically proves that China's listed SOEs managerial overconfidence is significantly related to financial distress, however the possibility of falling prey to financial distress varies depending on the type of ownership control (SAMBs, SOELGs, and SOECGs) responsible for managing firms' affairs. We observed that, in the presence of overconfident managers, SAMBs are the least likely to face financial distress followed by SOECGs, with SOELGs have the highest chance of falling into financial distress. This study contributes to the literature by providing evidence that lumping SOEs into one homogeneous group is biased as the different forms of ownership controls have unique characteristics.
\end{abstract}

Keywords: Overconfidence, Ownership Control, Financial Distress, Stateowned Enterprises, China.

\section{$\underline{\text { ARTICLE INFO }}$}

Article History:

Received: 12 February 2021

Accepted: 27 October 2021

Available online: 01 December 2021

\footnotetext{
* Corresponding Author: Abraham Simon Otim Emuron, School of Management and Economics, University of Electronic Science and Technology of China, Chengdu, China \& Center of West African Studies, University of Electronic Science and Technology of China, Chengdu, China. Qingshuihe Campus of UESTC, No. 2006, Xiyuan Avenue, West Hi-tech Zone, Chengdu, Sichuan, P.R. China, Zip/Postal Code: 611731; Email: abraham@std.uestc.edu.cn; wahida@uitm.edu.my; Tel: (+86) 132 81179562.
} 


\section{INTRODUCTION}

This study investigated the relationship between overconfident managers and firms facing financial distress within China's listed state-owned enterprises (SOEs). Borrowing from Chen, Firth, and Xu (2009) we categorized Chinese SOEs into three distinct forms of ownership, namely, state asset management bureaus (SAMBs), state owned enterprises (SOEs) affiliated to the central government (SOECGs), and SOEs affiliated to the local government (SOELGs). We argue that the different forms of ownership in China's SOEs have varying impacts on the performance of firms as their managers will also have different motivations and incentives to carry out their duties. Unlike past research that tended to lump Chinese SOEs into one homogeneous group, we predicted that the major differences in these three ownership structures plays a significant role on how managerial overconfidence affects the likelihood of such firms facing financial distress. As stated earlier, most literature examining China's SOEs tends to lump them into one group and therefore foregoing the fact that different forms of ownership within Chinas' SOEs have unique characteristics that affect the way they operate and are managed (Chen et al., 1998; Qi et al., 2000; Sun and Tong, 2003; Wang, 2005; Wei et al., 2003; Xu and Wang, 1998). These studies adopted a simplified categorization of ownership control that follows the legal classification of shares, that is, legal entity shares and state shares were identified as the two forms of ownership (Chen, Firth, and Rui, 2006). Wang (2003) further supported this notion by stating that these studies have critical biases on the actual reality as they ignored to establish the differences among the true owners and their motivations. Chen, Firth, and $\mathrm{Xu}(2009)$ developed this classification by identifying the economic and political interests of the aforementioned government institutions and then grouped them accordingly. Our study henceforth adopted this classification of ownership as it offers a better reflection of the objectives of the dominant shareholder as compared to using legal entity shares and state shares as forms of ownership.

In general overconfidence is defined as the tendency of individuals to overestimate their own acumen, mastery, and prospects for positive future outcomes. It has been observed that overconfident managers overestimate good investment opportunities and unconsciously magnify their benefits but underestimate the likelihood of adverse events ( $\mathrm{Li}$ et al., 2014). In addition, 
overconfident managers possess controlling illusions about the accuracy of their own judgment and the technologies they own. When making decisions, overconfident managers tend to overestimate the likelihood of success. They believe that their firms will have stellar performances and have great potential, and that outside investors underestimate their actual value (He, Chen \& Hu, 2018).

Such unwarranted behavior ends up with overconfident managers ignoring market factors, which leads to biased future expectations and results in continued investment expansion on unnecessary projects. We predicted that overconfidence among China's SOEs managers will have an impact on the financial health of the firms they operate in terms of financial distress. We also expected the effects of overconfidence to vary among the various forms of SOEs ownership. Our study therefore attempted to examine which forms of SOEs ownership were more/least likely to be prone to financial distress.

The following assumptions about overconfident managers and firms facing financial distress in China's SOEs were derived. SOELGs with overconfident managers were the most likely to face financial distress due to the weak monitoring and supervision standards that SOELGs received from the state authorities. Also, they are much further away from the centre of state governance hence providing them with opportunities to engage in value destroying activities. Next, we expected SAMBs with overconfident managers to be the least likely to face financial distress as they are purposed to achieve the state's political objectives therefore overshadowing any overconfidence traits that a manager may possess. Finally, this study predicted that SOECGs with overconfident managers will lie between the other two forms of ownership as managers in SOECGs are directly answerable to the central government as to the commercial performance of the firms hence strict monitoring is placed on them.

This paper makes a number of noteworthy contributions to the existing governance literature both in China and globally. First it provides evidence that different ownership structures within Chinas' SOEs have different operational and management standards. Second, it sheds light on which SOEs the government should increase monitoring to create value. Finally, this paper provides valuable insights for developing economies on how SOEs facing financial distress can address the issue of ownership structure when confronted with overconfident managers. 
The remainder of the paper is organized as follows. Section 2, consists of the literature review which provides background information on financial distress, managerial overconfidence and ownership structures within China's SOEs. The hypotheses are also developed in this section. Section 3 describes the methodology and provides details of the descriptive statistics. Section 4 presents and discusses the results from the analyses. Section 5 provides the conclusion to the study.

\section{LITERATURE REVIEW AND HYPOTHESES DEVELOPMENT}

There is limited literature that explores the effects of managerial overconfidence within Chinese listed SOEs let alone any that pays attention to the differences in forms of state ownership. With most literature focusing on lumping Chinese SOEs into one homogeneous group, there is an apparent gap in the literature and this paper attempts to identify the underlying dynamics of these relationships.

\section{Ownership Structure of Chinese SOEs}

Previous studies have highlighted the negative effects of the state's influence in listed firms, especially in the areas of governance and performance of the firms. Key literature in this field has stated the importance of no government interference in the running of listed firms (Boateng et al., 2019; Dewenter and Malatesta, 2001; Green, 2004; Megginson and Netter, 2001; Shleifer, 1998). This argument is similar in the case of China's SOEs where the state through different government institutions and departments has an active role in the operation of these listed firms. Chen, Firth, and $\mathrm{Xu}$ (2009) elaborated that these various government institutions and departments have different motivations and incentive structures and hence this will affect the manner in which the firms are ultimately run resulting in differences in performance or profitability for these firms. The differences in ownership result in certain firms being more prone to financial distress. However, a study carried out in Taiwan provided evidence of a positive relationship between firm value and ownership structures that are related to block-holders' ownership, foreign ownership, institutional ownership, and family ownership (Kao et al., 2019). Bircan (2019) also found a positive 
association between ownership structure and aggregate productivity growth in multinationals. We studied different ownership structures in Chinese SOEs in conjunction with the event where these firms may have an overconfident manager at the helm. Next, we give a brief summary of the different types of firm ownership in China's listed SOEs.

State asset management bureaus (SAMBs) are the means through which the Chinese government holds shares in listed firms. Managers within SAMBs are civil servants and are appointed through a political process (Qian, 1998; Zhang, 1998). These appointments are not based on the manager's business knowledge or industry expertise. SAMBs have been set up in various provinces to manage and operate state owned assets. Chen, Firth, and Xu (2009) also indicated that they sometimes own legal person shares of the listed firms they invest in.

SOEs affiliated to the central government (SOECGs) are SOEs operated by the central government under the State-owned Assets Supervision and Administration Commission (SASAC). These listed firms are a direct product of the central government and therefore are under significant scrutiny and management. Managers within SOECGs are appointed based on their expertise and ability to effectively carry out managerial duties in a firm. The central government has great influence over them and dictates their operations. And just as in the case of SAMBs, these firms are spread all over the country.

SOEs affiliated to local governments (SOELGs) are SOEs under the supervision of a local government. They are by far the largest group of controlling shareholders of listed companies in China (Chen, Firth, and $\mathrm{Xu}, 2009$ ). Just like SOECGs, managers in SOELGs are appointed based on their business expertise however, they differ from SOECGs, in that they are not under strict supervision and since they are much further away from the center of power (government) they are prone to flaunting the laws and regulations of China (Chen, Firth, and Xu, 2009).

\section{Managerial Overconfidence}

Overconfidence sometimes referred to as over optimism, is defined as the tendency of individuals to overestimate their own acumen, mastery, 
and prospects for positive future outcomes (Park et al. 2019). Overconfident managers have been known not to accurately assess negative results from the projects they oversee (Taylor and Gollwitzer, 1995; Taylor and Brown, 1988; Ahmed, 2013; Huang, 2013). Prior studies have shown that on the realization of negative feedback from a project, a rational manager will revise his/her expectations downward. However, in the case of an overconfident manger, he/she tends to overlook the negative feedback and rationalizes that the project still has a potential successful future (Kim, Wang and Zhang, 2016). Kim, Wang, and Zhang (2016) further add that these types of managers have a misperception of on-going negative net present value projects as value creating. Harvey et al., (2007) observed that overconfident managers underestimate the level of risk in judging future opportunities and therefore incorporate lower discount rates to value future expected cash flows. Previous studies have also concluded that overconfident managers underestimate risks, and overestimate profitability, future growth prospects, and expected returns thereby resulting in risky investment decisions (Hirshleifer et al., 2012). Apart from taking on risky investments, overconfident managers have been known to delay the release of information to company shareholders therefore resulting in a mismatch between the actual value of a firm and the value of the firm as reflected in the firm's stock price. Such scenarios increase the risks of stock crashes and the financial default of firms (Liang et al., 2020). It has also been noted that managerial overconfidence has resulted in many firms taking part in value-destroying mergers and acquisitions (Roll, 1986).

$\mathrm{He}$, Chen and $\mathrm{Hu}$ (2018) stated that in the case of China, there was a higher likelihood for SOEs with overconfident managers to engage in over investments as compared to non-SOEs. They further noted that the situation was exacerbated by the fact that managers who are appointed by the government usually lack the motivation to make sound financial decisions hence risking the potential for financial distress. Most managers within SOEs tend to focus more on their political careers hence they will often take decisions that do not make economic sense as regards the operations of the firms they manage. SOEs therefore offer overconfident managers the opportunity to be more rent seeking at the expense of the firm (Jiang et al., 2009). Such behaviors coupled with poor decision making open up SOEs to the possibility of financial distress. 
However, it should not be mistaken that managerial overconfidence is always detrimental to a firm's financial health. There are numerous instances as to when such a managerial trait becomes needful for the survival or positive performance of a firm (Mitra et al., 2019). It has been observed that in some financial crises having an overconfident manager has proved critical to the survival of the distressed firm as the overconfident managers were able to take riskier decisions that risk averse managers would not have taken. Overconfident manages too have been known to be in the forefront of new innovations and technologies that give their firms an edge over their competitors.

\section{Financial Distress}

A firm is said to be financially distressed when it is no longer able to meet its financial obligations and hence forced to undertake drastic actions to discharge its obligations, such as file for bankruptcy, undergo a troubled debt restructuring, sell assets at "fire-sale" prices, or be acquired by a financially stronger firm (Chang et al., 2015). There are other definitions in the literature that are used to describe financial distress, the most popular being Beaver (1966) who defined financial distress as a recourse to the judicial procedure of bankruptcy; default of debt repayment; excessive use of the banking overdraft; not paying dividends on preferred shares. We adopted the revised Altman Z-score model for emerging markets as a measure of financial distress, and explored how managerial overconfidence within the various forms of ownership in China's SOEs contribute to financial distress.

\section{Hypotheses Development}

Leng, Ozkan, and Trzeciakiewicz (2011) stated that financial distress can have major implications not only for shareholders and debt holders, but also for managers and other stakeholders. We focussed on whether overconfident managers have any effect on a firm's financial distress within the Chinese context. As stated, earlier overconfidence is manifested when people overestimate their own abilities and believe to be better than they actually are. Such overly optimistic managers henceforth overestimate their chances of success and underestimate their likelihood of failure (Graham et al., 2013). Graham et al. (2013) observed this behavioral bias more frequently among experts, including the Chief Executive Officers (CEOs) 
and managers of firms. Due to the fact that quite a number of managers in China's SOEs are political appointees and do not necessarily have a proper business acumen to manage a firm, we expect that there will be a higher likelihood for the firms they manage to encounter financial distress, especially when coupled with overconfidence. Previous studies have shown that these types of overconfident managers are more motivated to use debt financing as they believe the firm to be undervalued and less risky therefore not likely to face financial distress than it actually is (Hackbarth, 2008; Malmendier et al., 2011).

We therefore predicted that firms with overconfident managers in China's listed SOEs will most likely face financial distress. We developed the first hypothesis as follows:

H1: Ceteris paribus, overconfidence among managers in China's listed SOEs will lead to financial distress.

Next, we studied how managerial overconfidence within the different forms of ownership in China's SOEs affects the likelihood of firms facing financial distress. SAMBs are directly owned by the government or its agencies such as the Ministry of Finance or the State Council. The state invests heavily in SAMBs in terms of new capital injections, asset purchases and so forth. These types of firms are managed by civil servants appointed and paid by the government (Tang, 2016). Managers in these firms therefore do not receive any dividends or rewards from the firm, rather their promotion and career progress is largely attached to how well they follow instructions from the government. With the view that managers in SAMBs controlled firms neither bear the risks or the rewards associated with their performance we expected managerial overconfidence to have an overly significant effect on the financial distress of firms. We therefore developed the following hypothesis:

H2: Overconfident managers in SAMBs will have a positive effect on the financial distress of firms.

SOECGs are state owned enterprises affiliated to the central government while SOELGs are SOE affiliated to the local government. Unlike SAMBs, whose managers tend to be civil servants with no specific industry expertise, and are accustomed to the state bureaucracy and may be less cognizant of, 
or have less empathy with, commercial realities, SOECGs and SOELGs managers tend to have substantial and relevant industry experience (Chen, Firth and Rui, 2006). We therefore believed that overconfident managers in these types of firms will also have a positive effect on the firm's likelihood of facing financial distress. However, the degree of influence may vary based on the fact that even though both have experienced managers, SOECGs are put under greater scrutiny as compared to SOELGs. It is therefore expected that the effect of managerial overconfidence on firms' financial distress to be less within SOECGs than in SOELGs (Xu, 2004). Hence the following hypotheses:

H3: Overconfident managers in SOECGs will have a positive effect on the financial distress of firms.

H4: Overconfident managers in SOELGs will have a marginally higher positive effect on the financial distress of firms compared to SOECGs.

\section{RESEARCH METHODOLOGY}

This section provides details on the measures of dependent and independent variables of this study. Sample selection and descriptive statistics are also explained in this section.

\section{Financial Distress - Dependent Variable}

The main dependent variable was firms' financial distress, a dummy variable which equals 1 when a firm faced financial distress and, 0 otherwise. To classify whether a firm in a given year was in financial distress, this study adopted the inference approach and used the Altman Z-score (Altman 2000). This study followed prior studies (Kane et al., 2005; Al-Hadi et al., 2017) that employed the Altman Z-score as a proxy for financial distress. The financial distress variable (DISTRESS, hereafter) was measured as follows.

$$
\text { Zscore }=A \times 6.56+B \times 3.26+C \times 6.72+D \times 1.05+3.25
$$

Where $A$ stands for working capital/total assets; $B$ stands for retained earnings/total assets; $C$ stands for operating income/total assets, and $D$ stands for book value equity/total liabilities. 
A firm is defined to be 'distressed' if it's predicted Z-score was below zero for two continuous years.

DISTRESS $_{\mathrm{it}}=\left\{\begin{array}{l}1, \text { if predicted Zscore is below zero for two continuous } \\ \text { years, } 0, \text { otherwise. }\end{array}\right.$

\section{Independent Variables}

Overconfidence was the main independent variable of interest. Due to constraints in data availability within the Chinese market, we measured the overconfidence (OVERCONF, hereafter) variable through the use of firm earnings forecasts as they provide a better representation of managerial overconfidence (Hribar and Yang, 2011; Wang et al., 2008; He, Chen and $\mathrm{Hu}, 2018)$. Overconfident managers are prone to overestimating their abilities and their future firms' performances. Henceforth, if a firm's actual earnings were lower than the earnings expected by managers, we defined the managers as overconfident, with a dummy variable of 1 , and 0 otherwise.

The other main variables of interest in this study were: SAMBs $(S A M B$, hereafter), which was a dummy variable that equals 1 when the ultimate controlling shareholder is the state-owned asset management bureau in year $\mathrm{t}$, and 0 otherwise; SOELGs (SOELG, hereafter), which was a dummy variable that equals 1 when the ultimate controlling shareholder is state-owned enterprises related with the local government in year $\mathrm{t}$, and 0 otherwise; and SOECGs (SOECG, hereafter), which was a dummy variable that equals 1 when the ultimate controlling shareholder is state-owned enterprises related with the central government in year $t$, and 0 otherwise.

\section{Control Variables}

This study followed Nadeem (2019) and defined board size (BOARDSIZE) as the total number of directors on boards. Return on assets (PERFORM) was measured as the ratio of net income after tax to average total assets. Leverage ( $L E V E R A G E)$ was the debt-to-equity ratio. Net working capital $(N W C$ ) was measured as the ratio of working capital minus cash holdings to total assets. Collateral (COLLATERAL) was the ratio of fixed assets to total assets. Control rights $(C T R L)$ defined as the percentage of direct and indirect control rights of large shareholders. The basic and main regression model of this study was as follows. 


$$
\begin{aligned}
\text { DISTRESS }_{i t}= & \beta_{1} \text { OVERCONF }_{i t}+\beta_{2} \text { SAMB }_{i t}+\beta_{3} \text { SOELG }_{i t}+\beta_{4} \text { SOECG }_{i t} \\
& +\beta_{5} \text { COLLATERAL }_{i t}+\beta_{6} \text { BOARDSIZE }_{i t}+\beta_{7} \text { NWC }_{i t}+ \\
& \beta_{8} \text { PERFORM }_{i t}+\beta_{9} \text { LEVERAGE }_{i t}+\varepsilon_{i t}
\end{aligned}
$$

\section{Model Estimation}

We tested our hypotheses by using logistic regressions and the maximum likelihood estimations as derived below (Rodriguez 2007).

The probability distribution function of $Y_{i}$ was given by,

$$
\operatorname{Pr}\left\{Y_{i}=y_{i}\right\}=\left(\begin{array}{c}
n_{i} \\
y_{i}
\end{array}\right) \pi_{i}^{y_{i}}\left(1-\pi_{i}\right)^{n_{i}-y_{i}}
$$

for $y_{i}=0,1, \ldots, n i$. Here $\pi_{i}^{\mathrm{yi}}\left(1-\pi_{i}\right)^{n i-y i}$ is the probability of obtaining $y i$ successes and $n_{i}-y_{i}$ failures in some specific order, and the combinatorial coefficient is the number of ways of obtaining $y_{i}$ successes in $n_{i}$ trials.

Taking logs we find that, except for a constant involving the combinatorial terms, the log-likelihood function is,

$$
\log L(\beta)=\sum\left\{y_{i} \log \left(\pi_{i}\right)+\left(n_{i}-y_{i}\right) \log \left(1-\pi_{i}\right)\right\}
$$

where $\pi_{i}$ depends on the covariates $x_{i}$ and a vector of $p$ parameters $\beta$ through the logit transformations.

Given a current estimate $\widehat{\beta}$ of the parameters, we calculate the linear predictor $\eta^{\hat{n}}=\mathrm{x}_{i}^{\prime} \widehat{\beta}$ and the fitted values $\hat{\mu}=\operatorname{logit}^{-1}(\eta)$. With these values we calculate the working dependent variable $z$, which has elements,

$$
z_{i}=\hat{\eta}_{i}+\frac{y_{i}-\hat{\mu}_{i}}{\hat{\mu}_{i}\left(n_{i}-\hat{\mu}_{i}\right)} n_{i}
$$

where $n_{i}$ are the binomial denominators. We then regress $z$ on the covariates calculating the weighted least squares estimate

$$
\widehat{\beta}=\left(\mathbf{X}^{\prime} \mathbf{W} \mathbf{X}\right)^{-1} \mathbf{X}^{\prime} \mathbf{W} \mathbf{z}
$$


where $\mathbf{W}$ is a diagonal matrix of weights with entries

$$
w_{i i}=\hat{\mu}_{i}\left(n_{i}-\hat{\mu}_{i}\right) / n_{i}
$$

For hypotheses $H 2, H 3$ and $H 4$ we examined the effects of overconfident managers within the different forms of SOEs ownership structures and on firms' financial distress. The ownership structures investigated were SAMBs, SOELGs, and SOECGs, this study interacted the overconfidence variable with the different ownership structures and the models are shown below respectively:

$$
\begin{aligned}
\text { DISTRESS }_{i t}= & \beta_{1} \text { OVERCONF }_{i t}+\beta_{2} \text { SAMB }_{i t}+\beta_{3} \text { SOELG }_{i t}+\beta_{4} \text { SOECG }_{i t} \\
& +\beta_{5} \text { SAMB }^{*} \text { OVERCONF } \\
& +\beta_{7} \text { BOARDSIZE }_{i t}+\beta_{8} \text { COLLC }_{i t}+\beta_{9} \text { PERFORALM }_{i t} \\
& +\beta_{10}{ }_{\text {LEVERAGE }}+\varepsilon_{i t}
\end{aligned}
$$

$$
\begin{aligned}
\text { DISTRESS }_{i t}= & \beta_{1} \text { OVERCONF }_{i t}+\beta_{2} \text { SAMB }_{i t}+\beta_{3} \text { SOELG }_{i t}+\beta_{4} \text { SOECG }_{i t} \\
& +\beta_{5} \text { SOELG }_{i t} * \text { OVERCONF } \\
& +\beta_{i t} \text { BOARDSIZE }_{i t}+\beta_{6} \text { COLLATERAL }_{i t} C_{i t}+\beta_{9} \text { PERFORM }_{i t} \\
& +\beta_{10} \text { LEVERAGE }_{i t}+\varepsilon_{i t}
\end{aligned}
$$

$$
\begin{aligned}
\text { DISTRESS }_{i t}= & \beta_{1} \text { OVERCONF }_{i t}+\beta_{2} \text { SAMB }_{i t}+\beta_{3} \text { SOELG }_{i t}+\beta_{4} \text { SOECG }_{i t} \\
& +\beta_{5} \text { SOECG }_{i t} * \text { OVERCONF }_{i t}+\beta_{6} \text { COLLATERAL }_{i t} \\
& +\beta_{7} \text { BOARDSIZE }_{i t}+\beta_{8} N W C_{i t}+\beta_{9} \text { PERFORM }_{i t} \\
& +\beta_{10} \text { LEVERAGE }_{i t}+\varepsilon_{i t}
\end{aligned}
$$

\section{Sample}

We use data obtained from the China Stock Market. Due to infrequent trading of the B-shares and their relatively small number, we utilized the A-shares traded on the Shanghai Stock Exchange (SHSE) and the Shenzhen Stock Exchange (SZSE) during the period 2003-2018. Our sample started from 2003 as this was the year in which compulsory disclosure of controlling shareholders data in annual financial statements was implemented. For all the listed firms, we took great care to identify the major shareholder and true owner before we grouped them into the various ownership types namely, SAMBs, SOECGs, and SOELGs. The following firms are excluded from the sample: (1) firms in the financial sector; (2) delisted firms, ST (Special 
Treatment) firms; (3) firms with missing information on control rights; and (4) firms with missing financial information. The data is based on annual observations and taken from the China Stock Market and Accounting Research (CSMAR) and the Wind database.

\section{Descriptive Statistics}

Our final data consisted of 16,601firm-year observations. The number of years available for each firm varied. The sample included 2933 unique firms. Table 1 (Panel A) reports a summary of all variables. The mean values for COLLATERAL, NWC, PERFORM and LEVERAGE were 0.212 , $0.165,8.244$, and 1.146 respectively. The results were consistent with previous studies focusing on the China (Nadeem, 2019; Liu et al., 2014). Table 2 (Panel B) shows the summary statistics by the type of controlling shareholder. On average, all firms had at least nine board directors. In terms of profitability (PERFORM), SOECGs were the best performers followed by SOELGs. SAMBs are the worst, these results were also in line with prior studies (Chen, Firth and $\mathrm{Xu}, 2009$ ). To eliminate any possibilities of multicollinearity, variance inflation factors (VIFs) were measured for the independent variables, and un-reported results showed that the highest VIF was 9.16 , which demonstrated that multicollinearity was not significant within this data.

Table 1: (Panel A). Descriptive Statistics

\begin{tabular}{lcccc}
\hline Variables & Mean & SD & Min & Max \\
\hline DISTRESS & 0.028 & 0.164 & 0 & 1 \\
OVERCONF & 0.013 & 0.113 & 0 & 1 \\
SAMB & 0.263 & 0.440 & 0 & 1 \\
SOELG & 0.049 & 0.217 & 0 & 1 \\
SOECG & 0.032 & 0.177 & 0 & 1 \\
COLLATERAL & 0.212 & 0.165 & 0 & 0.929 \\
BOARDSIZE & 8.717 & 1.782 & 4 & 18 \\
NWC & 0.165 & 0.185 & -2.153 & 0.872 \\
PERFORM & 8.244 & 6.340 & -56.269 & 53.449 \\
LEVERAGE & 1.146 & 2.670 & -35.176 & 71.397 \\
CTRL & 0.286 & 0.197 & 0 & 0.948 \\
\hline
\end{tabular}

This table presents descriptive statistics of the dependent and independent variables. All variables are defined in the Appendix. 
Table 2: (Panel B). Summary statistics:

SAMBs

\section{By Type of Controlling Shareholders}

\begin{tabular}{lcccc}
\hline & Mean & SD & Min & Max \\
\hline PERFORM & 8.511 & 27.035 & -1456.312 & 159.965 \\
NWC & 0.084 & 0.179 & -0.566 & 0.917 \\
BOARDSIZE & 9.619 & 2.071 & 4 & 19 \\
LEVERAGE & 1.935 & 4.262 & -51.215 & 194.792 \\
COLLATERAL & 0.286 & 0.197 & 0 & .948
\end{tabular}

\section{SOECGs}

\begin{tabular}{lcccc} 
PERFORM & 9.098 & 12.561 & -112.744 & 60.353 \\
NWC & 0.136 & 0.169 & -0.82 & 0.65 \\
BOARDSIZE & 9.525 & 2.012 & 4 & 17 \\
LEVERAGE & 1.451 & 3.567 & 0.033 & 70.736 \\
COLLATERAL & 0.249 & 0.191 & 0.001 & 0.861 \\
& & & & \\
SOELGs & & & & \\
PERFORM & 8.519 & 11.441 & -112.707 & 66.311 \\
NWC & 0.079 & 0.191 & -1.83 & 0.837 \\
BOARDSIZE & 9.844 & 1.912 & 5 & 17 \\
LEVERAGE & 1.355 & 1.991 & 0.034 & 45.874 \\
COLLATERAL & 0.33 & 0.212 & 0.001 & 0.96 \\
\hline
\end{tabular}

This table presents descriptive statistics by type of controlling shareholders. All variables are defined in the Appendix

\section{RESULTS AND DISCUSSION}

Regression results for hypothesis $H 1$ are shown in Table 3. Odds ratio estimates are shown for the independent variables as they are much more convenient to interpret and give a clearer explanation as to the relationship between the dependent and predictor variables. The odds ratios are the exponentials of the estimates for each respective variable. We used the McFadden R-square in our analyses. Model fit was low with an R-square of $4.9 \%$, and this is in line with similar studies that examined the different ownership structures in China's SOEs namely, SAMBs, SOECGs, and SOELGs. Our main variables of interest (OVERCONF, SAMB, SOECG, and SOELG) were all significant except for SOECG. OVERCONF had an odds ratio of greater than 1 (1.511), and a positive coefficient. This indicated that there was a $51 \%$ increase in odds that China's SOEs with overconfident managers will most likely face financial distress. Next, we discuss the 
results for the different forms of ownership. $S A M B$ had an odds ratio of 1.373 , therefore SAMBs had a $37 \%$ higher chance in odds of becoming financially distressed while SOELGs denoted by SOELG had a (odds ratio: 1.571) $57 \%$ increase in odds to fall prey to financial distress. On the other hand, SOECGs denoted by SOECG had a (odds ratio: 1.198 ) $20 \%$ increase in odds to face financial distress. Overall, these results supported our first hypothesis $H 1$ that managerial overconfidence within China's listed SOEs will have a significant and positive effect of firms encountering financial distress. The analysis also showed that SOELGs are the most likely to face financial distress followed by SAMBs with SOECGs in the middle. This result supported the argument that SOELGs are the least supervised and further from the center of government control hence they are most likely to engage in value destroying activities leading to financial distress. SOECGs are the least likely to face financial distress and this result is consistent with prior literature, Chen, Firth, and Xu (2009) who observed that SOECGs are usually the best performing SOEs. We attribute this to the strict monitoring from the central government and skilled management appointed to oversee SOECGs.

Table 3: Regression for the Association between Financial Distress and Overconfidence

\begin{tabular}{lcc}
\hline \multicolumn{1}{c}{ Dependent variable } & DISTRESS & Odds Ratio (OR) \\
OVERCONF & $0.413^{*}$ & 1.511 \\
& $(0.194)$ & \\
SAMB & $0.317^{* * *}$ & 1.373 \\
SOELG & $(-0.317)$ & 1.571 \\
& $0.452^{*}$ & \\
SOECG & $(0.250)$ & 1.198 \\
& 0.180 & \\
COLLATERAL & $(0.262)$ & 1.863 \\
& $0.622^{*}$ & \\
BOARDSIZE & $(0.293)$ & 1.365 \\
NWC & $0.311^{* * *}$ & 4.815 \\
PERFORM & $(0.013) 1.572^{* * *}$ & 1.033 \\
& $(0.235)$ & \\
LEVERAGE & $0.0328^{* * *}$ & 0.997 \\
Observations & $(0.007)$ & - \\
McFadden $R^{2}$ & $-0.003^{* * *}$ & \\
\hline This table reports the results of the impact of overconfidence on financial distress. The odds ratios (OR) are reported. All \\
variables are defined in the Appendix. ${ }^{* * *},{ }^{* * *}$ represent significance at $0.1,0.05$ and 0.01 levels, respectively.
\end{tabular}


Next, we investigated the effects of overconfident managers in each of the various forms of ownership structures in Table 4. Columns 1 and 2 of Table 4 examined the interaction term between overconfidence and SAMBs $\left(S A M B^{*} O V E R C O N F\right)$. The interaction term was statistically significant at $10 \%(\mathrm{p}<0.1)$ with a negative coefficient. The odds ratio was 0.744 which meant that SAMBs with overconfident managers are $26 \%$ less likely in odds to face financial distress. This implies that managerial overconfidence at SAMBs has a minor contribution towards financial distress as compared to SOELGs and SOECGs. This outcome is due to the fact that SAMBs unlike SOECGs and SOELGs are heavily supported and influenced by the government therefore they are more of political vehicles geared to achieve government objectives and less of commercial activities. Therefore, managers' overconfidence behavioral traits tend to get overshadowed by the state's agenda. Columns 3 and 4 of Table 4 displays the results of the third hypothesis $H 3$ which focussed on the interaction term between SOELGs and overconfidence (SOELG*OVERCONF). The odds ratio of 1.913 reflected that SOELGs with overconfident managers had a $91 \%$ increase in odds of facing financial distress. As argued earlier, the lax monitoring standards that SOELGs receive from the state authorities left them susceptible to financial distress, however this situation was exacerbated when SOELGs have an overconfident manager. Columns 5 and 6 of Table 4 represent the final hypothesis $H 4$ which studied the effects of overconfident of managers in SOECGs (SOECG*OVERCONF) on the possibility of financial distress. SOECG ${ }^{*} O V E R C O N F$ had a positive coefficient and an odds ratio of 1.317. This estimate was interpreted as SOECGs have a $32 \%$ increase in odds of facing financial distress with overconfident managers in charge. In summary, among the three ownership structures studied with overconfident managers at the helm, SOELGs are the most likely to face financial distress followed by SOECGs, with SAMBs being the least likely to encounter financial distress because of the influence of overconfident managers. 
Table 4: Regressions for the Association between Financial Distress and Overconfidence among the different forms of ownership

\begin{tabular}{|c|c|c|c|c|c|c|}
\hline & $\mathrm{H}$ & 2 & $\mathbf{H}$ & 3 & $\mathrm{H}$ & 4 \\
\hline & $\begin{array}{l}\text { DISTRESS } \\
\text { (1) }\end{array}$ & $\begin{array}{l}\text { OR } \\
(2)\end{array}$ & $\begin{array}{l}\text { DISTRESS } \\
\text { (3) }\end{array}$ & $\begin{array}{l}\text { OR } \\
\text { (4) }\end{array}$ & $\begin{array}{l}\text { DISTRESS } \\
\text { (5) }\end{array}$ & $\begin{array}{l}\text { OR } \\
(6)\end{array}$ \\
\hline OVERCONF & $\begin{array}{l}0.727^{* *} \\
(0.269)\end{array}$ & 1.176 & $\begin{array}{c}0.377^{*} \\
(0.194)\end{array}$ & 1.458 & $\begin{array}{c}0.404^{*} \\
(0.196)\end{array}$ & 1.497 \\
\hline$S A M B$ & $\begin{array}{c}0.374^{* * *} \\
(0.112)\end{array}$ & 1.625 & $\begin{array}{c}0.320^{* * *} \\
(0.107)\end{array}$ & 1.377 & $\begin{array}{l}0.318^{* *} \\
(0.107)\end{array}$ & 1.374 \\
\hline SOELG & $\begin{array}{c}0.450 \\
(0.249)\end{array}$ & 2.059 & $\begin{array}{c}0.388 \\
(0.250)\end{array}$ & 1.474 & $\begin{array}{c}0.451 \\
(0.245)\end{array}$ & 1.570 \\
\hline SOECG & $\begin{array}{l}0.173^{*} \\
(0.262)\end{array}$ & 1.357 & $\begin{array}{l}0.182^{*} \\
(0.262)\end{array}$ & 1.199 & $\begin{array}{l}0.161^{*} \\
(0.271)\end{array}$ & $\begin{array}{c}1.175 \\
-\end{array}$ \\
\hline SAMB*OVERCONF & $\begin{array}{l}-0.703^{*} \\
(0.360)\end{array}$ & 0.744 & - & - & - & - \\
\hline SOELG*OVERCONF & & & $\begin{array}{c}0.649 \\
(0.252)\end{array}$ & 1.913 & $\begin{array}{l}- \\
-\end{array}$ & \\
\hline SOECG*OVERCONF & & & & & $\begin{array}{l}0.275^{\star} \\
(1.068)\end{array}$ & 1.317 \\
\hline COLLATERAL & $\begin{array}{l}0.646^{*} \\
(0.294)\end{array}$ & 0.899 & $\begin{array}{l}0.620^{*} \\
(0.293)\end{array}$ & 3.300 & $\begin{array}{l}0.624^{*} \\
(0.293)\end{array}$ & 1.866 \\
\hline BOARDSIZE & $\begin{array}{c}0.308^{* * *} \\
(0.013)\end{array}$ & 0.933 & $\begin{array}{c}0.311^{* * *} \\
(0.013)\end{array}$ & 1.3993 & $\begin{array}{l}0.311^{* * *} \\
(0.013)\end{array}$ & 1.365 \\
\hline NWC & $\begin{array}{l}1.572^{* * *} \\
(0.236)\end{array}$ & 1.644 & $\begin{array}{l}1.584^{* * *} \\
(0.238)\end{array}$ & 7.767 & $\begin{array}{l}1.571^{* * *} \\
(0.235)\end{array}$ & 4.811 \\
\hline PERFORM & $\begin{array}{c}0.034^{* * *} \\
(0.007)\end{array}$ & 1.008 & $\begin{array}{c}0.033^{* * *} \\
(0.007)\end{array}$ & 1.047 & $\begin{array}{c}0.033^{* * *} \\
(0.007)\end{array}$ & 1.033 \\
\hline LEVERAGE & $\begin{array}{l}-0.002 \\
(0.013)\end{array}$ & 0.988 & $\begin{array}{l}-0.003 \\
(0.013)\end{array}$ & 1.023 & $\begin{array}{l}-0.003 \\
(0.013)\end{array}$ & 0.997 \\
\hline Observations & 16601 & & 16601 & & 16601 & \\
\hline McFadden $\mathrm{R}^{2}$ & $4.8 \%$ & & $4.9 \%$ & & $4.9 \%$ & \\
\hline
\end{tabular}

This table reports the results of the association between financial distress and overconfidence among different forms of ownership. The odds ratios (OR) are reported. All variables are defined in the Appendix. ${ }^{*},{ }^{* *},{ }^{* * *}$ represent significance at $0.1,0.05$ and 0.01 levels, respectively.

\section{Robustness Checks}

In this section we discuss a potential problem with our results which is endogeneity or reverse causality. Issues of endogeneity are common in studies focusing on corporate governance (Sila, Gonzalez and Hagendorff, 2016). Omitted variables and self-selection are two aspects of endogeneity that our study may have encounterd. It is conceivable that firm and governance characteristics both observable and unobservable may have an effect on a firm's financial distress. Also, when the state decides to list its firms on the public stock exchange, it may allocate the more productive and 
profitable units of SOEs, to a specific type of owner (SAMBs, SOELGs, or SOECGs). If this is the scenario, it then becomes slightly complicated to ascribe a firm's likelihood of facing financial distress to the influence of an overconfident manager (Chen, Firth and Xu, 2009). Previous studies have adopted the use of instrumental variable regression to deal with omitted variables and the use of Heckman's two-stage model to deal with selfselection bias (Sila et al., 2016; Lara et al., 2017, respectively).

To appropriately use an instrumental variable regression, there is need to select a variable that is similar to the independent variables but has no effect on the explanatory variable. We adopted to use control rights (CTRL, hereafter) as an exogenous instrumental variable and used the two stage least squares estimator to account for endogeneity resulting from omitted variable bias. The reasoning behind using the use CTRL is that it has an impact on SAMBs, SOELGs, and SOECGs but does not have effects on DISTRESS. For the two stage least squares we used the predicted values of $C T R L\left(C T R L^{\wedge}\right)$ in the second stage with DISTRESS as the dependent variable. The results of the regression are shown in column 1 of Table 5. The coefficient of interest $C T R L^{\wedge}$ was positive and significant (0.01), suggesting that main results are true after controlling for omitted variable bias.

We used Heckman's two-stage model to address the self-selection problem (Heckman 1979). In the first stage model, we identified all those variables that could potentially affect a firm's financial distress and run a probit regression. We then used the predicted values to calculate the inverse Mills ratio (IMR). This probit model controls for firm characteristics. In the second stage, the IMR was then added to the model as an additional variable to control for self-selection bias. We present the results of the Heckman two-stage regression in column 2 of Table 5. 
Table 5: Two-stage and Heckman Estimation

\begin{tabular}{|c|c|c|}
\hline & 2SLS & Heckman \\
\hline Dependent variable & $\begin{array}{c}\text { DISTRESS } \\
\text { (1) }\end{array}$ & $\begin{array}{c}\text { DISTRESS } \\
(2) \\
\end{array}$ \\
\hline OVERCONF & $\begin{array}{c}-0.014^{*} \\
(0.50)\end{array}$ & $\begin{array}{l}1.318^{* *} \\
(2.53)\end{array}$ \\
\hline$S A M B$ & - & $\begin{array}{l}0.090 \\
(0.71)\end{array}$ \\
\hline SOELG & $\begin{array}{l}- \\
-\end{array}$ & $\begin{array}{l}0.469 \\
(1.70)\end{array}$ \\
\hline SOECG & - & $\begin{array}{c}0.688 \\
(0.318)\end{array}$ \\
\hline COLLATERAL & $\begin{array}{l}0.015 \\
(0.77)\end{array}$ & $\begin{array}{c}1.668^{* * *} \\
(4.30)\end{array}$ \\
\hline BOARDSIZE & $\begin{array}{c}0.005^{\star * *} \\
(4.85)\end{array}$ & $\begin{array}{c}0.752^{\star \star \star} \\
(7.66)\end{array}$ \\
\hline NWC & $\begin{array}{l}0.027^{*} \\
(1.57)\end{array}$ & $\begin{array}{c}2.605^{* * *} \\
(5.64)\end{array}$ \\
\hline PERFORM & $\begin{array}{l}0.001^{*} \\
(0.36)\end{array}$ & $\begin{array}{c}0.097^{* * *} \\
(6.05)\end{array}$ \\
\hline LEVERAGE & $\begin{array}{c}0.004^{* * *} \\
(3.88)\end{array}$ & $\begin{array}{c}-0.042^{* * *} \\
(-3.34)\end{array}$ \\
\hline IMR & $\begin{array}{l}- \\
-\end{array}$ & $\begin{array}{c}4.404^{\star \star *} \\
(3.29)\end{array}$ \\
\hline$C T R L^{\wedge}$ & $\begin{array}{c}0.008^{* * *} \\
(4.23)\end{array}$ & $\begin{array}{l}- \\
-\end{array}$ \\
\hline McFadden $\mathrm{R}^{2}$ & $3.8 \%$ & $2.8 \%$ \\
\hline
\end{tabular}

This table reports the two-stage least-square and Heckman estimations of the impact of ownership control on financial distress. $C T R{ }^{\wedge}$ are the predicted values of control rights instrumented with SAMBs, SOELGs and SOECGs. IMR is the Inverse Mills ratio used to control for self-selection bias in the second stage of Heckman estimation. T-statistics are reported in parentheses. All variables are defined in the Appendix. ${ }^{*},{ }^{* *}$ and ${ }^{* *}$ represent significance at $0.1,0.05$ and 0.01 levels, respectively.

\section{CONCLUSION}

This study examined the relationship between financial distress and managerial overconfidence in Chinas' listed SOEs by accounting for the different forms of ownership structures. We documented differences in the likelihood of firms to face financial distress across China's listed SOEs from 2003 to 2018. This study empirically showed that Chinas' listed SOEs managerial overconfidence was significantly related to financial distress, however the possibility of falling prey to financial distress varied depending 
on the type of ownership control (SAMBs, SOELGs, and SOECGs) responsible for managing the firms' affairs. We observed that, in the absence of overconfident managers, SOECGs are the least likely to face financial distress followed by SAMBs, with SOELGs having the highest chance of falling into financial distress.

We then investigated specific situations, in which overconfident managers are at the helm of SAMBs, SOELGs and SOECGs. Our findings indicated that SOELGs were still the most prone to face distress with the situation being amplified by overconfident managers. The lack of strict oversight and monitoring offers overconfident managers the opportunity to engage in risky and value destroying activities. However, in the case of SAMBs the effects of overconfident managers tended to subside. We attribute this to the political objectives of SAMBs which overshadow the managerial overconfidence traits. SOECGs are the middle as they are closely monitored by the central government and have appointed skilled managers. This offers insights to policy makers on which SOEs to place more focus to mitigate the negative effects of overconfident managers.

Using the odds ratios, we specifically estimated the likely increase/ decrease for listed SOEs in China to fall into financial distress when managed by overconfident managers. Although our results suggested that overconfidence in Chinas' listed SOEs plays a role in causing financial distress, they should be interpreted cautiously. Our analysis cannot totally exclude other aspects that affect a firm's financial health. However, the introduction of the various forms of ownership and not the usual lumping of Chinas' SOEs into one homogeneous group does improve our understanding of the effects of overconfidence in such firms. Future research should increase the sample studied by including both private and non-state publicly listed firms.

\section{REFERENCES}

Ahmed, A. S. \& Duellman, S. (2013). Managerial overconfidence and accounting conservatism. Journal of Accounting Research, 51, 1-30. 
Al-Hadi, A., Chatterjee, B., Yaftian, A., Taylor, G. \& Hasan, M. M. (2017). Corporate social responsibility performance, financial distress and firm life cycle: evidence from Australia. Accounting and Finance, 59, 921-1446.

Altman, I. (2000). Predicting Financial Distress of Companies: Revisiting the Z-score and Zeta Model. New York: New York University.

Bircan, Ç. (2019). Ownership Structure and Productivity of Multinationals. Journal of International Economics, 116, 125-143. https://doi. org/10.1016/j.jinteco.2018.11.005Get

Beaver, W. H. (1966). Financial ratios as predictors of failure. Journal of Accounting Research,4, 71-111.

Boateng, A., Liu, Y. \& Brahma, S. (2019). Politically connected boards, ownership structure and credit risk: Evidence from Chinese commercial banks. Research in International Business and Finance, 47, 162173. https://doi.org/10.1016/j.ribaf.2018.07.008

Chang, W., Hayes, R. \& Hillegeist, S. A. (2015). Financial distress risk and new CEO compensation. Management Science, 62, 479-501

Chen, G., Firth, M. \& Rui, O. M. (1998). The economic performance of privatized firms in China. Working Paper. The Hong Kong Polytechnic University.

Chen, G., Firth, M. \& Rui, O. M. (2006). Have China's reforms led to improved efficiency and profitability? Emerging Markets Review, 7, 82-109.

Chen, G., Firth, M. \& Xu, L. (2009). Does the type of ownership control matter? Evidence from China's listed companies. Journal of Banking \& Finance, 33, 171-181.

Dewenter, K. L. \& Malatesta, P. H. (2001). State-owned and privately owned firms: an empirical analysis of profitability, leverage and labor intensity. American Economic Review, 91, 320-334. 
Graham, J. R., Harvey, C. R. \& Puri, M. (2013). Managerial attitudes and corporate actions. Journal of Financial Economics, 109, 103-121.

Green, S. (2004). The privatization two-step at China's listed firms. Working Paper, Chatham House.

Harvey, C. R., Ben-David, I. \& Graham, J. R. (2007). Managerial overconfidence and corporate policies. National Bureau of Economic Research.

Hackbarth, D. (2008). Managerial traits and capital structure decisions. Journal of Financial and Quantitative Analysis, 43, 843-881.

He, Y., Chen, C. \& Hu, Y. (2018). Managerial overconfidence, internal financing, and investment efficiency: Evidence from China. Research in International Business and Finance, 47, 501-510.

Heckman, J. J. (1979). Sample selection bias as a specification error. Econometrica, 153- 161.

Hirshleifer, D., Low, A. \& Teoh, S. H. (2012). Are overconfident CEOs better innovators? The Journal of Finance, 67, 1457-1498.

Hribar, B. P. \& Yang, H. (2011).CEO overconfidence and management forecasting, SSRN Electronic Journal https://doi.org/10.2139/ ssrn. 929731 .

Huang, J. \& Kisgen, D. J. (2013). Gender and corporate finance: are male executives overconfident relative to female executives? Journal of Financial Economics, 108, 822-839.

Jiang, F. X., Yin, Z. H., Su, F. \& Huang, L. (2009). Managerial background traits and corporate over-investment. Management World, 1, 130-139.

Kane, G. D., Velury, U. \& Ruf, B. M. (2005). Employee relations and the likelihood of occurrence of corporate financial distress. Journal of Business Finance and Accounting, 32, 1083-1105. 
Kao, M.-F., Hodgkinson, L. \& Jaafar, A. (2019). Ownership structure, board of directors and firm performance: evidence from Taiwan. Corporate Governance, 19(1), 189-216. https://doi.org/10.1108/CG-04-2018-0144

Kim, J. B., Wang, Z. \& Zhang, L. (2016). CEO overconfidence and stock price crash risk. Contemporary Accounting Research, 33, 1720-1749.

Lara, J. M. G., Osma, B. G., Mora, A. \& Scapin, M. (2017). The monitoring role of female directors over accounting quality. Journal of Corporate Finance, 45:651-668.

Leng, J., Ozkan, A. \& Trzeciakiewicz, A. (2011). Can managerial overconfidence lead firms to bankruptcy? Evidence from UK. Retrieved from https://efmaefm.org/0efmaMilan/papers/EFMA2018_0504_ fullpaper.pdf.

Li, W. L., Xie, G. L. \& Hao, J. Y. (2014). The empirical study on the influence of managerial overconfidence on overinvest behavior. Journal of Shanxi Finance and Economics University, 10, 76-86.

Liang, Q., Ling, L., Tang, J., Zeng, H. \& Zhuang, M. (2020). Managerial overconfidence, firm transparency, and stock price crash risk: Evidence from an emerging market. China Finance Review Internationa. 10(3), 271-296. https://doi.org/10.1108/CFRI-01-2019-0007

Liu, Y., Wei, Z. \& Xie, F. (2014). Do women directors improve firm performance in China? Journal of Corporate Finance, 28, 169-184.

Malmendier, U., Tate, G. \& Yan, J. (2011). Overconfidence and earlylife experiences: the effect of managerial traits on corporate financial policies. The Journal of Finance, 66, 1687-1733.

Megginson, W. L. \& Netter, J. M. (2001). From state to market: A survey of empirical studies on privatization. Journal of Economic Literature, 39, 321-389.

Mitra, S., Jaggi, B. \& Al-Hayale, T. (2019). Managerial overconfidence, ability, firm-governance and audit fees. Review of Quantitative Finance 
and Accounting. 52, 841-870. https://doi.org/10.1007/s11156-0180728-3

Nadeem, M. (2019). Does board gender diversity influence voluntary disclosure of intellectual capital in IPO prospectuses? Evidence from China. Corporate Governance: An International Review, forthcoming.

Park, K.-H., Byun, J. \& Choi, P.M.S. (2019). Managerial overconfidence, corporate social responsibility activities, and financial constraints. Sustainability, 12(1), 61. https://doi.org/10.3390/ su12010061

Qi, D., Wu, W. \& Zhang, H. (2000). Shareholding structure and corporate performance of partially privatized firms: Evidence from listed Chinese companies. Pacific-Basin Finance Journal, 8, 587-610.

Qian, Y. (1998). Government control in corporate governance as a transitional institution: lessons from China. Working Paper. Stanford University.

Rodriguez, G. (2007). Logit models for binary data. [Document file]. Retrieved from http://data.princeton.edu/wws509/notes/c3.pdf.

Roll, R. (1986). The hubris hypothesis of corporate takeovers. The Journal of Business, 59, 197-216.

Shleifer, A. (1998). State versus private ownership. Journal of Economic Perspectives, 12, 133-150.

Sila V, Gonzalez A. \& Hagendorff, J. (2016). Women on board: Does boardroom gender diversity affect firm risk? Journal of Corporate Finance, 36, 26-53.

Sun, Q. \& Tong, W. (2003). China share issue privatization: The extent of its success. Journal of Financial Economics, 70, 183-222.

Taylor, S. E. \& Brown, J. D. (1988). Illusion and well-being: A social psychological perspective on mental health. Psychological Bulletin, 103, 193-210. 
Taylor, S. E. \& Gollwitzer, P. M. (1995). Effects of mindset on positive illusions. Journal of Personality and Social Psychology, 69, 213-226.

Tang, Y. H. (2016). Privatization, tunneling, and tax avoidance in Chinese SOEs. Asian Review of Accounting, 24, 274 - 294.

Wang, C. (2005). Ownership and operating performance of Chinese IPOs. Journal of Banking and Finance, 29, 1835-1856.

Wang, J. (2003). Governance role of different types of state-shareholders: Evidence from China's listed firms. Ph.D. thesis, Hong Kong University of Science and Technology.

Wang, X., Zhang, M. \& Yu, F. S. (2008). CEO overconfidence and distortion of firms' investments: some empirical evidence from China. Nankai Business Review, 11, 77-83.

Wei, Z., Varela, O., D’Souza, J. \& Hassan, M. K. (2003). The financial and operating performance of China's newly privatized firms. Financial Management, 32, 107- 126.

Xu, L. (2004). Types of large shareholders, corporate governance, and firm performance. Working Paper. Zhongshan University.

Xu, X. \& Wang, Y. (1998). Ownership structure, corporate governance, and corporate performance: The case of Chinese stock companies. Working Paper. The World Bank, Washington DC.

Zhang, X. (1998). China's SOE reform: a corporate governance perspective. Working Paper. Peking University. 


\section{APPENDIX}

\section{Variable names and definitions}

\begin{tabular}{l}
\hline \multicolumn{1}{c}{ Variables } \\
\hline Dependent Variable \\
DISTRESS \\
Independent Variables \\
OVERCONF
\end{tabular}

OVERCONF

SOECG

SOELG

$S A M B$

Control Variables

NWC

PERFORM

LEVERAGE

BOARDSIZE

COLLATERAL

CTRL
Dummy variable which equals 1 when a firm faces financial distress and, 0 otherwise.

Dummy variable which equals to 1 when manager is overconfident and, 0 otherwise.

Dummy variable which equals to 1 when the ultimate controlling shareholder is state-owned enterprises related with central government in year $t$, and 0 otherwise.

Dummy variable which equals to 1 when the ultimate controlling shareholder is state-owned enterprises related with local government in year $\mathrm{t}$, and 0 otherwise.

Dummy variable which equals to 1 when the ultimate controlling shareholder is state-owned asset management bureau in year $\mathrm{t}$, and 0 otherwise.

Ratio of working capital minus cash holdings to total assets.

The ratio of net income after tax to average total assets.

Debt to equity ratio.

Total number of directors on boards.

Ratio of fixed assets to total assets.

Percentage of direct and indirect control rights of large shareholders 